\title{
RETRACTED: KAJIAN SOSIOLOGI SASTRA DALAM NOVEL HABIBIE DAN AINUN KARYA BACHARUDDIN JUSUF HABIBIE
}

\author{
M. A Nurkholis ${ }^{1^{*}}$, Ari Setiyanto ${ }^{2}$ \\ ${ }^{1}$ Dosen Sekolah Tinggi Ekonomi Dan Bisnis Islam Darussalam OKI \\ 2 Dosen Sekolah Tinggi Ekonomi Dan Bisnis Islam Darussalam OKI \\ Email: Anwarnurkholis28@gmail.com
}

RETRACTED

Setelah ditinjau dengan cermat dan dipertimbangkan artikel yang dipublikasikan di Jurnal Seulas Pinang: Jurnal Pendidikan Bahasa dan Sastra Indonesia dengan judul "Kajian Sosiologi Sastra dalam Novel Habibie dan Ainun Karya Bacharuddin Jusuf Habibie" Vol. 2, No. 1, hlm. 43-49, Oktober 2020, DOI: https://doi.org/10.30599/spbs.v2i1.821. Makalah ini telah ditemukan melanggar ketentuan terbitan Jurnal Seulas Pinang: Jurnal Pendidikan Bahasa dan Sastra Indonesia dan telah dicabut. Editor menyelidiki dan menemukan bahwa makalah tersebut diterbitkan dalam Jurnal LINGUA, JURNAL BAHASA \& SASTRA, Vol. 21, No. 1, Desember 2020, hlm. 10-18, https://ejournal.unsri.ac.id/index.php/lingua/article/download/14211/6124. Dokumen dan isinya telah dihapus dari Jurnal Seulas Pinang: Jurnal Pendidikan Bahasa dan Sastra Indonesia, dan upaya yang wajar harus dilakukan untuk menghapus semua referensi ke artikel ini. 